\title{
Torturous journeys: Cruelty, international law, and pushbacks and pullbacks over the Mediterranean Sea
}

\author{
Jamal Barnes* (D) \\ Edith Cowan University, Joondalup, Western Australia \\ *Corresponding author. Email: j.barnes@ecu.edu.au
}

(Received 21 October 2020; revised 27 December 2021; accepted 26 January 2022; first published online 28 February 2022)

\begin{abstract}
Boat pushbacks and pullbacks by Italy and the European Union (EU) have returned migrants and refugees to Libya where they have been subjected to brutal human rights violations, such as torture and ill-treatment. This article argues that these pushbacks and pullbacks not only undermine key human rights principles, but they are also an act of cruelty. As Italy and the EU have used the law to evade their international human rights and refugee obligations, the law has had distributive effects that have shaped migration pathways and exacerbated the vulnerability of migrants and refugees to torture. Not only have legal manoeuvres stripped migrants and refugees of their rights, enabling Italy and the EU to return people to inhumane detention centres in Libya, but they have also had the sinister side effect of excluding migrants and refugees from moral concern. As Italy and the EU have sought to evade legal responsibility, it has created indifference to the suffering of people on the move in Libya. This article sheds important light on the factors that lead to the torture of migrants and refugees on their migration journeys and offers new insights into the relationship between cruelty, migration policies, and indifference to human suffering.
\end{abstract}

Keywords: International Law; Cruelty; Torture; Refugees and Migrants; Europe; Boat Pushbacks and Pullbacks

\section{Introduction}

As part of efforts to stop irregular boat arrivals to European shores, European countries have developed a number of cooperative agreements with North African countries, such as Libya, to intercept migrant boats in the Mediterranean Sea and return them to their country of departure. Known as 'pushback' ${ }^{\text {' }}$ and 'pullback' ${ }^{2}$ operations, Europe has deemed them as important in preventing deaths at sea and in disrupting the activities of people smugglers. However, despite European countries arguing that these cooperative agreements have been effective, human rights

\footnotetext{
${ }^{1}$ Pushbacks are defined 'as various measures taken by States, sometimes involving third countries or non-State actors, which result in migrants, including asylum seekers, being summarily forced back, without an individual assessment of their human rights protection needs, to the country or territory, or to sea, whether it be territorial waters or international waters, from where they attempted to cross or crossed an international border.' United Nations, Report on Means to Address the Human Rights Impact of Pushbacks of Migrants on Land and At Sea: Report of the Special Rapporteur on the Human Rights of Migrants, Felipe González Morales, Human Rights Council, Doc. No. A/HRC/48/30 (2021), p. 4.

${ }^{2}$ Pullbacks are defined as 'operations [that] are designed to physically prevent migrants from leaving the territory of their State of origin or a transit State (retaining State), or to forcibly return them to that territory, before they can reach the jurisdiction of their destination State'. See United Nations Human Rights Council, Report of the Special Rapporteur on Torture and Other Cruel, Inhuman or Degrading Treatment or Punishment, Doc. No. A/HRC/37/50 (2018), p. 16.

(C) The Author(s), 2022. Published by Cambridge University Press on behalf of the British International Studies Association. This is an Open Access article, distributed under the terms of the Creative Commons Attribution licence (https://creativecommons.org/licenses/by/4.0/), which permits unrestricted re-use, distribution, and reproduction in any medium, provided the original work is properly cited.
} 
groups and international organisations have documented how returned migrants have been exposed to inhumane detention, torture, extortion, slavery, rape, and unlawful killings. ${ }^{3}$

The significant risks migrants and refugees ${ }^{4}$ face on their migration journeys raise serious questions about the role that migration deterrence policies are playing in exacerbating the vulnerability of people on the move. ${ }^{5}$ Scholars have shown how European border policies have undermined international refugee and human rights law, ${ }^{6}$ failed to provide protection for migrants ${ }^{7}$ (especially women), ${ }^{8}$ constructed the migrant's life as 'unworthy' of being saved, ${ }^{9}$ and increased the risk of death in the Mediterranean Sea. ${ }^{10}$ The result is that already precarious migration journeys become even more dangerous, exposing people to unnecessary pain and suffering as people flee violence or widespread poverty in their home country.

This article builds upon this scholarship to argue that European pushback and pullback policies are exacerbating the vulnerability of migrants and refugees to torture and ill-treatment. The vulnerability of people to torture on their migration journeys is not the result of the inevitable effects of moving between sovereign states. Rather, it is the product of the distributive effects of deliberately chosen policies. Actors, such as Italy and the European Union (EU), have narrowly interpreted their international legal obligations to implement policies that both enable pushbacks and pullbacks, while at the same time, allow them to evade their human rights obligations to migrants and refugees. Although the purpose of these cooperative policies is to restrict people arriving in Europe, these policies have had serious side effects. Instead of using the law to develop safe migration pathways for migrants, ${ }^{11}$ Italy and the EU are using the law to remove important

\footnotetext{
${ }^{3}$ See, for example, Amnesty International, Libya's Dark Web of Collusion: Abuses against Europe-Bound Refugees and Migrants (London, UK: Amnesty International Ltd, 2017), available at: \{https://www.amnesty.org/en/documents/mde19/ 7561/2017/en/\}; Human Rights Watch, No Escape from Hell: EU Policies Contribute to Abuse of Migrants in Libya (2019), available at: \{https://www.hrw.org/report/2019/01/21/no-escape-hell/eu-policies-contribute-abuse-migrants-libya\}; United Nations General Assembly, Report of the Special Rapporteur of the Human Rights Council on Extrajudicial, Summary or Arbitrary Executions, Doc. No. A/73/314 (7 August 2018).

${ }^{4}$ This article defines 'international migrants' as 'any person who is outside a State of which he or she is a citizen or national, or, in the case of a stateless person, his or her State of birth or habitual residence'. See United Nations Office of the High Commissioner of Human Rights, Recommended Principles and Guidelines on Human Rights at International Borders (2014), available at: \{https://www.ohchr.org/Documents/Issues/Migration/OHCHR_Recommended_Principles_Guidelines.pdf\}. The article defines refugees in accordance with Art. 1 of the 1951 Convention Relating to the Status of Refugees. See: \{https://www.unhcr. org/en-au/3b66c2aa10\}.

${ }^{5}$ See Reece Jones, Violent Borders: Refugees and the Right to Move (London, UK and New York, NY: Verso, 2017).

${ }^{6}$ See, for example, Thomas Gammeltoft-Hansen, Access to Asylum: International Refugee Law and the Globalisation of Migration Control (Cambridge, UK: Cambridge University Press, 2011); Guy S. Goodwin-Gill, 'The rights to seek asylum: Interception at sea and the principle of non-refoulement', International Journal of Refugee Law, 23:3 (2011), pp. 443-57; Andreas Fischer-Lescano, Tillmann Löhr, and Timo Tohidipur, 'Border controls at sea: Requirements under international human rights and refugee law', International Journal of Refugee Law, 21:2 (2009), pp. 256-96; Maarten Den Heijer, 'Reflections on refoulement and collective expulsion in the Hirsi case', International Journal of Refugee Law, 25:2 (2013), pp. 265-90; Natasa Mavronicola, 'Hirsi Jamaa v. Italy: Human rights and expulsion on the high seas', Cyprus Human Rights Law Review, 1:2 (2012), pp. 198-211.

${ }^{7}$ Alexander Betts and Paul Collier, Refuge: Transforming a Broken Refugee System (London, UK: Penguin Books, 2018).

${ }^{8}$ Jane Freedman, 'Engendering security at the borders of Europe: Women migrants and the Mediterranean "crisis", Journal of Refugee Studies, 29:4 (2016), pp. 568-82.

${ }^{9}$ Tugba Basaran, 'The saved and the drowned: Governing indifference in the name of security', Security Dialogue, 46:3 (2015), pp. 205-20; Luca Mavelli, 'Governing populations through the humanitarian government of refugees: Biopolitical care and racism in the European refugee crisis', Review of International Studies, 43 (2017), pp. 809-32; Vicki Squire, 'Governing migration through death in Europe and the US: Identification, burial and the crisis of modern humanism', European Journal of International Relations, 23:3 (2017), pp. 513-32.

${ }^{10}$ See, for example, Thomas Spijkerboer, 'The human costs of border control', European Journal of Migration and Law, 9:1 (2007), pp. 127-39; Forensic Oceanography, Death by Rescue: The Lethal Effects of the EU's Policies of Non-Assistance (London, UK: Goldsmiths, University of London, 2016). See: \{https://deathbyrescue.org\}.

${ }^{11}$ Commissioner for Human Rights, Lives Saved, Rights Protected: Bridging the Protection Gap for Refugees and Migrants in the Mediterranean, Council of Europe (2019), pp. 45-7, available at: $\{$ https://rm.coe.int/lives-saved-rights-protected-bridgingthe-protection-gap-for-refugees-/168094eb87\}.
} 
human rights and refugee protections, resulting in distributive effects that are making migration pathways more dangerous.

The idea that the law has distributive effects or can be used to legitimise harm is not new. ${ }^{12}$ But what has not been adequately examined is how focusing on these distributive effects can shed light on how states and other international actors can engage in cruelty. European officials may not be on the ground in Libya engaging in torture. But they are implementing policies that are contributing to cruel behaviour. As Zygmunt Bauman ${ }^{13}$ notes, cruelty can be exercised from a distance by implementing bureaucratic rules and laws that play a part in inflicting pain upon others. Not only has the manipulation of the law stripped migrants and refugees of their rights, exacerbating their vulnerability and enabling Italy and the EU to return them to inhumane detention centres in Libya, but it has also had the sinister effect of excluding migrants and refugees from moral concern. As states engage in legal manoeuvres to evade legal responsibility, it is creating moral indifference to the pain and suffering of migrants and refugees. ${ }^{14}$ As this article shows, cruelty does not just occur through violations of the law. Depending on how the law is used, it can help create the conditions that make cruelty possible.

The first section of this article defines the concept of cruelty. The second section then explores how the strategic use of law shapes migration pathways through its distributive effects. The third section turns to the analysis of Europe's pushback and pullback policies in the Mediterranean Sea. The analysis focuses specifically on the pushbacks and pullbacks carried out by Italy and the EU, as these actors have been leading the way in developing these policies to prevent people crossing the central Mediterranean. The fourth section then looks at challenges to pullbacks. Not only does this article contribute to understanding how migrants and refugees become vulnerable to torture on their migration journeys, something that is currently under-studied, ${ }^{15}$ but it can also advance a novel understanding of the relationship between cruelty, migration control, and indifference to human suffering.

\section{Conceptualising cruelty and indifference}

It may sound unusual to accuse Italy and the EU of engaging in cruelty. Cruelty is a particular category of pain and suffering that is often reserved for those considered 'barbaric' and 'uncivilised'. ${ }^{16}$ For Judith N. Shklar, cruelty is the 'worst thing' that someone can do to another. ${ }^{17}$ And for Etienne Balibar, cruelty constitutes something 'worse than death' ${ }^{18}$ International law prohibits torture $^{19}$ and cruel and inhuman treatment absolutely, and the torture prohibition is considered a form of customary international law. ${ }^{20}$

\footnotetext{
${ }^{12}$ See, for example, Ian Hurd, How to Do Things with International Law (Princeton, NJ and and Oxford, UK: Princeton University Press, 2017); David Kennedy, Of War and Law (Princeton, NJ and Oxford, UK: Princeton University Press, 2006); David Kennedy, A World of Struggle (Princeton, NJ and Oxford, UK: Princeton University Press, 2018); Scott Veitch, Law and Irresponsibility: On the Legitimation of Human Suffering (Oxon, UK: Routledge, 2007); Jamal Barnes, 'Australia, US torture and the power of international law', Australian Journal of Political Science, 54:4 (2019), pp. 474-89.

${ }^{13}$ Zygmunt Bauman, Modernity and the Holocaust (Cambridge, UK: Polity Press, 1989).

${ }^{14}$ On how the law creates moral indifference, see also Basaran, 'The saved and the drowned'.

${ }^{15}$ Pau Pérez-Sales, 'Migration and torture: Building a map of knowledge', Torture Journal: Journal on Rehabilitation of Torture Victims and Prevention of Torture, 28:2 (2018), pp. 1-14 (p. 10).

${ }^{16}$ See Jamal Barnes, A Genealogy of the Torture Taboo (Abingdon, UK: Routledge, 2017).

${ }^{17}$ Judith N. Shklar, Ordinary Vices (Cambridge and London, UK: Harvard University Press, 1984).

${ }^{18}$ Etienne Balibar, 'Outlines of a topography of cruelty: Citizenship and civility in the era of global violence', Constellations, 8:1 (2001), pp. 15-29 (p. 15).

${ }^{19}$ This article defines 'torture' in accordance with Article $1(1)$ of the UN Convention against Torture. See: \{https://www. ohchr.org/en/professionalinterest/pages/cat.aspx\}.

${ }^{20}$ See Nigel S. Rodley with Matt Pollard, The Treatment of Prisoners Under International Law (3rd edn, New York, NY: Oxford University Press, 2009), pp. 76-7.
} 
Although there is no definition of 'cruel' under international treaties, ${ }^{21}$ the Macquarie Dictionary defines 'cruel' as 'disposed to inflict suffering; indifferent to, or taking pleasure in, the pain or distress of another; hard-hearted; pitiless'. ${ }^{22}$ Understanding cruelty as intentionally inflicting pain upon another person for pleasure may bring to mind the behaviour of the sadistic torturer. However, focusing on intent to harm for pleasure does not reflect the cruelty exercised by European actors in pushbacks and pullbacks. Italy and the EU are not authorising torture or sending migrants and refugees back to Libya with the specific intent for them to be tortured. Italian or EU officials are not the ones inflicting torture on migrants and refugees in Libyan detention centres, with the Libyan officials and other non-state actors, such as human smugglers, engaging in the torture. ${ }^{23}$ And there is no evidence to suggest European actors feel pleasure from seeing the torture in Libya.

Rather, Italy and the EU have engaged in cruelty by demonstrating indifference ${ }^{24}$ to the infliction of pain and suffering of people that has resulted from pushbacks and pullbacks. European actors have sought to cooperate with Libya on migration issues to prevent migrant arrivals, save migrant deaths at sea, and to dismantle people trafficking networks. ${ }^{25}$ In pursuit of these policies, they have privileged migrant deterrence goals over preventing harm to migrants. Cruelty does not just occur when actors possess a specific intent to hurt others. As the definition of cruelty above demonstrates, and as others have noted, ${ }^{26}$ cruelty is also exercised when actors show an indifference to the pain they inflict upon others. Randall Collins refers to this category of cruelty as 'callous cruelty', which is a 'kind of hardship or violence people may inflict on others without a special intent to hurt. The subject of the violence is simply an instrument or an obstacle, and his suffering is merely an incidental (usually ignored) feature of some other intention. ${ }^{27}$ In the case of European pushbacks and pullbacks, the cruelty is exercised as these actors pursue migration deterrence goals, ignoring the pain and suffering that is occurring largely as a result.

It is not unusual for cruelty to be exercised by actors without pleasure or a specific intent to harm. In Hannah Arendt's work on the Nazi Adolf Eichmann, she argued that he did not represent the personification of 'radical evil' but was a 'normal' person who was unable to think about or empathise with the victims of his actions. Eichmann was more interested in following the law and administrative procedures than principles of morality, even when following the laws and rules resulted in human suffering. ${ }^{28}$ Likewise, Stanley Milgram's experiment on obedience to authority demonstrated how 'everyday' people were able to administer what they thought were electric shocks onto another person if an authority figure told them to do so. ${ }^{29}$ Milgram's subjects were not aggressive or hostile towards the person receiving the fake electric shocks, and there was no evidence that participants deliberately wanted to hurt the 'victim' or took pleasure in inflicting pain. Even when the person who pretended to receive the 'electric shocks' cried out in pain, the majority of participants continued administering the electric shocks

\footnotetext{
${ }^{21}$ See Rodley with Pollard, The Treatment, pp. 125-31.

${ }^{22}$ Macquarie Dictionary, available at: $\{$ https://www.macquariedictionary.com.au/\}.

${ }^{23}$ See Amnesty International, Dark Web of Collusion.

${ }^{24}$ 'Indifference' is defined as 'lack of interest or concern'. See Macquarie Dictionary, available at: \{https://www.macquariedictionary.com.au/\}. On indifference and cruelty, see John Kekes, 'Cruelty and liberalism', Ethics, 106:4 (1996), pp. 834-44.

${ }^{25} \mathrm{On}$ EU and Libyan cooperation on migration matters, see, for example, European External Action Service, 'Speech by the HRVP Federica Mogherini at the Visit to EUNAVFOR Operation Sophia' (8 February 2017), available at: \{https://www.operationsophia.eu/wp-content/uploads/2018/04/eeas_-_european_external_action_service_speech_by_the_hrvp_federica_mogherini_at_the_visit_to_eunavfor_operation_sophia_-_2017-05-08.pdf\}.

${ }^{26}$ See Kekes, 'Cruelty and liberalism'.

${ }^{27}$ Randall Collins, 'Three faces of cruelty: Towards a comparative sociology of violence', Theory and Society, 1:4 (1974), pp. $415-40$ (p. 432).

${ }^{28}$ Hannah Arendt, Eichmann in Jerusalem: A Report on the Banality of Evil (London, UK: Penguin Books, 2006).

${ }^{29}$ Stanley Milgram, Obedience to Authority: An Experimental View (London, UK: Tavistock Publications Ltd, 1974).
} 
when told to do so by the experimenter, privileging the experimenter's authority over the suffering of the 'victim'. ${ }^{30}$

As it is Libyan actors, not European ones, that are physically torturing migrants in Libya, integral to understanding the cruelty exercised by the EU and Italy is exploring how cruelty can be inflicted from a distance through the use of laws, rules, and bureaucratic procedures. ${ }^{31}$ Bauman has analysed how bureaucratic machinery has been integral in the execution of immoral acts, such as the Holocaust. He argues that bureaucratic structures make it easier to engage in cruelty as it creates a separation between the perpetrator and victim. Bureaucrats and lawmakers are not directly inflicting pain and suffering upon others. Rather, the infliction of harm comes from simply implementing rules that have been sanctioned by the state. Bauman, following Hannah Arendt's work on Adolf Eichmann, ${ }^{32}$ argues that the cruelty of the Holocaust was not often carried out by those with personal predispositions to inflict cruelty, but rather by 'ordinary' people implementing policies and tasks from behind a bureaucratic desk. ${ }^{33}$

The reason why 'ordinary' people are able to carry out widespread forms of cruelty, such as during the Holocaust, is because it is easier to exercise cruelty from a distance. As bureaucratic rules and laws create physical and psychological distance between the victims and the perpetrators, it diminishes the 'moral significance of the $\mathrm{act}^{34}$ and makes it easier to inflict pain upon others. The rules act as a type of 'buffer' that reduces moral concern for victims. ${ }^{35}$ This is because working within a bureaucratic chain makes one only an intermediary, not the person that is inflicting the pain upon another person. ${ }^{36}$ As a result, it becomes easier to ignore any responsibility for that harm ${ }^{37}$ and it can create moral indifference as bureaucratic actions place victims beyond concern. ${ }^{38}$ As Milgram noted, 'This may illustrate a dangerously typical situation in complex society: it is psychologically easy to ignore responsibility when one is only an intermediate link in a chain of evil action but is far from the final consequences of the action. Even Eichmann was sickened when he toured the concentration camps, but to participate in mass murder he had only to sit at a desk and shuffle papers. ${ }^{39}$

Focusing on the use of laws and rules sheds important light on how Italy and the EU are engaging in cruelty through pushbacks and pullbacks. Italy and the EU are engaging in cruelty by crafting laws and policies that assist in intercepting boats and returning them into harm's way. Although European actors are not engaging in torture in Libya themselves, these pushback and pullback policies are perpetuating and contributing to the infliction of torture and illtreatment of migrants and refugees. In addition, following these laws and policies have helped create moral indifference to the treatment of returned migrants. Italy and the EU have interpreted international law in a manner that allows them to avoid legal responsibility for boat interceptions and returns. It is by denying legal responsibility over migrants on the high seas that not only makes it easier to return people into harm's way, but also severs any obligation to them as

\footnotetext{
${ }^{30}$ Milgram, Obedience to Authority.

${ }^{31}$ See Bauman, Modernity and the Holocaust.

${ }^{32}$ Arendt, Eichmann in Jerusalem; Hannah Arendt, 'Thinking and moral considerations: A lecture', Social Research, 38:3 (1971), pp. 417-46.

${ }^{33}$ Bauman, Modernity and the Holocaust, p. 166. See also Milgram, Obedience to Authority.

${ }^{34}$ Bauman, Modernity and the Holocaust, p. 25; see also Collins, 'Three faces of cruelty', pp. 432-4.

${ }^{35}$ Milgram, Obedience to Authority, p. 157.

${ }^{36}$ Bauman, Modernity and the Holocaust, p. 161.

${ }^{37}$ Ibid.

${ }^{38}$ Ibid., p. 193.

${ }^{39}$ Ibid., p. 11.
} 
they are placed beyond moral concern. As analysed in detail below, despite proclamations that EU officials care about the well-being of migrants, ${ }^{40}$ Italy and the EU continue to send migrants back to Libya with full knowledge of the human rights abuses that occur there. ${ }^{41}$

The role that the law can play in generating indifference to suffering has been recognised by others. Tugba Basaran, for example, has explored how imposing legal sanctions and threatening prosecutions on search and rescue operations can generate indifference to people drowning at sea. ${ }^{42}$ As people become fearful of being prosecuted for rescuing migrants at sea, it generates changes in the normative environment that casts migrants as being unworthy of being saved. However, what Bauman highlights is how laws and bureaucratic procedures can also generate indifference by removing moral responsibility for the act. ${ }^{43}$ When a violent act has been sanctioned by laws and rules, and an actor is not physically engaging in the violence, they may feel neither morally nor legally responsible for the action, making it easier to carry it out. ${ }^{44}$

The advantage of defining European pushback and pullback policies as cruel is that not only does it acknowledge the harm inflicted upon migrants, but it also recognises the element of indifference that is created by how laws and rules have been shaped. In doing so, it helps to further understand the ongoing tolerance of human suffering as European actors pursue migration deterrence goals. However, if the EU and Italy are engaging in cruelty, how is cruelty carried out at a distance? The answer lies in how European pushback and pullback policies create and distribute vulnerability along migration journeys.

\section{Constructing vulnerability through pushbacks and pullbacks}

To argue that Italy and the EU are narrowly defining international law to enable and legitimise pushbacks and pullbacks is not new. It has been widely recognised within the migration and refugee literature that states have strategically used international law to narrow their obligations under international human rights and refugee law. ${ }^{45}$ Because the meaning of law is contested, and is shaped through practice, it provides different actors with the opportunity to shape and interpret the law in particular directions. ${ }^{46}$ Strategically using international law has been crucial in legitimising migration deterrence policies and controlling refugee movements. ${ }^{47}$ Policies such as pushbacks and pullbacks, expulsions, and extraterritorial and arbitrary detention, among other deterrence policies, have been implemented not by avoiding international law but using it in a way that adheres to the letter but not the spirit of the law. ${ }^{48}$ This is what Zoltán I. Búzás has called 'bad-faith compliance or evasion', a practice that straddles between legality and illegality by

\footnotetext{
${ }^{40}$ See, for example, Letter from Mr Luigi Di Maio, Minister of Foreign Affairs and International Cooperation of Italy, to Ms Dunja Mijatovic, Commissioner for Human Rights, Council of Europe (20 February 2020), available at: \{https://www.coe.int/ en/web/commissioner/-/commissioner-urges-italy-to-suspend-co-operation-activities-with-libyan-coast-guard-and-introduce-human-rights-safeguards-in-future-migration-co-opera\}.

${ }^{41}$ See Amnesty International, Dark Web of Collusion; Human Rights Watch, No Escape from Hell.

${ }^{42}$ Basaran, 'The saved and the drowned'.

${ }^{43}$ Bauman, Modernity and the Holocaust. Veitch has also shown how the law can create irresponsibility for harm. See Veitch, Law and Irresponsibility.

${ }^{44}$ Milgram, Obedience to Authority, p. 122.

${ }^{45}$ See Gammeltoft-Hansen, Access to Asylum.

${ }^{46}$ See Kennedy, A World of Struggle.

${ }^{47}$ See Thomas Gameltoft-Hansen and Tanja Aalberts, 'Search and rescue as a geopolitics of international law', in Tanja Aalberts and Thomas Gammeltoft-Hansen (eds), The Changing Practices of International Law (New York, NY: Cambridge University Press, 2019), pp. 188-207; Alise Coen, 'Can't be held responsible: Weak norms and refugee protection evasion', International Relations, 35:2 (2019), pp. 341-62; Lama Mourad and Kelsey P. Norman, 'Transforming refugees into migrants: Institutional change and the politics of international protection', European Journal of International Relations, 26:3 (2019), pp. 687-713.

${ }^{48}$ David Scott Fitzgerald, Refuge Beyond Reach: How Rich Democracies Repel Asylum Seekers (New York, NY: Oxford University Press, 2019).
} 
'following the letter of the law but violating its purpose (spirit) in order to minimize inconvenient obligations in a way that is arguably legal'. ${ }^{49}$ Evasion helps states avoid liability, making it harder for courts to hold them accountable for their actions. ${ }^{50}$ David Kennedy argues that this means that international law can not only help generate progressive outcomes that constrain states, but these legal struggles can also produce harm, leaving some people vulnerable, as actors bend the law to advance their interests. ${ }^{51}$

The vulnerability of migrants and refugees to torture on their migration journeys is the side effect of how Italy and the EU have interpreted their international legal obligations. By narrowly defining the non-refoulement principle as well as the concept of legal jurisdiction, it chips away at important human rights and refugee protections. As explained in more detail below, asylum seekers and refugees do not undergo interviews for refugee protection when intercepted at sea or have the right to apply for asylum. ${ }^{52}$ They are returned to Libya where they have faced inhumane, arbitrary detention and torture, are prevented from leaving Libya, or are returned to a third country where they face torture. ${ }^{53}$ Moreover, Libya does not offer protection to returnees, and there is no mechanism within pushback and pullback agreements that can suspend the arrangement because of human rights abuses. ${ }^{54}$ Weakening these human rights protections through legal interpretation has enabled policies that push and pull people into torture chambers and leave them vulnerable to violence and abuse along their migration journey.

As a result, the significant weakening of human rights protections under pushbacks and pullbacks shapes migration pathways but it also creates vulnerability. Vulnerability refers to the possibility that one "may be wounded'. ${ }^{55}$ Although vulnerability is a universal characteristic of being human, ${ }^{56}$ it is at the same time not equally shared. Vulnerability is not distributed evenly, and the source of this uneven distribution is often from how political and legal institutions have been shaped. ${ }^{57}$ That is, the source of vulnerability to torture along migration routes is not the inevitable result of migrant and refugee movements, but created by the side effects of state policies and legal frameworks. This gives rise to what Catriona Mackenzie, Wendy Rogers, and Susan Dodds call situational vulnerability. This is vulnerability that is context specific at a particular point in time. ${ }^{58}$ But this situational vulnerability can also have pathogenic effects, whereby laws, policies, and political arrangements exacerbate vulnerability. ${ }^{59}$

\footnotetext{
${ }^{49}$ Zoltán I. Búzás, 'Evading international law: How agents comply with the letter of the law but violate its purpose', European Journal of International Relations, 23:4 (2017), pp. 857-83 (p. 858).

${ }^{50}$ Búzás, 'Evading international law'.

${ }^{51}$ Kennedy, A World of Struggle.

${ }^{52}$ See Hirsi Jamaa and Others v. Italy, European Court of Human Rights, Application No. 27765/09 (2012); see Amnesty International, Dark Web of Collusion.

${ }^{53}$ Human Rights Watch, Pushed Back, Pushed Around: Italy's Forced Return of Boat Migrants and Asylum Seekers, Libya's Mistreatment of Migrants and Asylum Seekers (2009), available at: $\{$ https://www.hrw.org/report/2009/09/21/pushed-backpushed-around/italys-forced-return-boat-migrants-and-asylum-seekers\}.

${ }^{54}$ Committee on Migration, Refugees and Displaced Persons, Human Rights Impact of the 'External Dimension' of European Union and Migration Policy: Out of Sight, Out of Rights?, Council of Europe Parliamentary Assembly (June 2018), Doc. 14575, p. 11, available at: $\{$ https://pace.coe.int/en/files/24808\#trace-2\}.

${ }^{55}$ Robert E. Goodin, Protecting the Vulnerable: A Reanalysis of Our Social Responsibilities (Chicago, IL and London, UK: The University of Chicago Press, 1985), p. 110.

${ }^{56}$ See Bryan S. Turner, Vulnerability and Human Rights (University Park, PA: The Pennsylvania State University Press, 2006); Martha Albertson Fineman, 'The vulnerable subject: Anchoring equality in the human condition', Yale Journal of Law \& Feminism, 20:1 (2008), pp. 1-23.

${ }^{57}$ See Catriona Mackenzie, Wendy Rogers, and Susan Dodds (eds), Vulnerability: New Essays in Ethics and Feminist Philosophy (New York, NY: Oxford University Press, 2014); Ian Clark, The Vulnerable in International Society (Oxford, UK: Oxford University Press, 2013).

${ }^{58}$ Catriona Mackenzie, Wendy Rogers, and Susan Dodds, 'Introduction: What is vulnerability and why does it matter for moral theory?', in Mackenzie, Rogers, and Dodds (eds), Vulnerability, pp. 7-9.

${ }^{59}$ Mackenzie, Rogers, and Dodds, 'Introduction', p. 9.
} 
Pushbacks and pullbacks are a clear example of where policies have been pursued that exacerbate the vulnerability of migrants. European states and institutions have had the opportunity to make migration pathways safer. As the European Commissioner for Human Rights has recommended, this could be by playing a larger role in resettlement schemes, supporting humanitarian visas and family unification programmes, as well as providing greater opportunities for labour and study visas. ${ }^{60}$ Instead, European actors are deterring migrants, in turn making migration pathways more dangerous. ${ }^{61}$ Alongside narrowly defining non-refoulement and jurisdiction to restrict migrant and refugee rights, EU member states have concluded readmission agreements to assist returns to countries of origin, ${ }^{62}$ as well as support Libya and neighbouring countries, such as Egypt and Algeria, with border control measures to prevent migration movements. ${ }^{63}$

In addition, in 2017, Italy implemented a code of conduct that restricted the ability for NGOs to engage in search and rescue operations. ${ }^{64}$ Italy has also restricted NGO rescue vessels from docking in Italian ports, threatening NGOs that rescue migrants at sea with prosecution. ${ }^{65}$ As a result, several NGOs have decided to stop search and rescue missions because of both the restrictions as well as threats they were receiving from the Libyan Coast Guard (LCG). ${ }^{66}$ This ensured that LCG pullback operations have gone ahead unimpeded, ${ }^{67}$ increasing the likelihood that migrants would be intercepted by the LCG and returned to detention centres in Libya.

Focusing on how political and legal arrangements can create situational vulnerability to torture is particularly relevant for migrants and refugees because of their dependence on states to offer them safety and security. As Ian Clark notes, 'While refugees are at first vulnerable to the original conditions that give them cause for flight, they then confront a double jeopardy in their subsequent exposure to the decisions of powerful others about whether or not to admit them for protection. ${ }^{.68}$ Vulnerability to torture and cruel treatment along migration routes, therefore, is not a natural consequence of migration journeys. As Robert E. Goodin argues, 'any dependency or vulnerability is arguably created, shaped, or sustained, at least in part, by existing social arrangements. None is wholly natural. ${ }^{69}$ The refusal to implement alternative policies that create more humane and safe migration pathways in favour of migration deterrence policies demonstrates that migration journeys do not have to be dangerous. Rather, they have been made dangerous by implementing specifically designed policies.

Bauman's study on the role of bureaucracies and laws in exercising cruelty at a distance can show how focusing on the creation and distribution of vulnerability creates a link between European migration policy and torture of migrants in Libya. Italy and the EU are facilitating the return of migrants and refugees to Libya, helping detain them in inhumane detention centres,

\footnotetext{
${ }^{60}$ Commissioner for Human Rights, Lives Saved, pp. 45-7.

${ }^{61}$ This has been recognised by the UN Special Rapporteur on Torture. See United Nations Human Rights Council, Report of the Special Rapporteur.

${ }^{62}$ Committee on Migration, Refugees and Displaced Persons, Human Rights, p. 12. See also Council of Europe, Report to the Italian Government on the Visit to Italy Carried out by the European Committee for the Prevention of Torture and Inhuman or Degrading Treatment or Punishment (CPT) (27 to 31 July 2009), available at: \{https://rm.coe.int/1680697276\} p. 9.

${ }^{63}$ See European Commission, 'Joint Communication to the European Parliament, the European Council and the Council: Migration on the Central Mediterranean Route: Managing Flows, Saving Lives' (25 January 2017), available at: \{https://eurlex.europa.eu/resource.html?uri=cellar:6e6590bb-e2fa-11e6-ad7c-\}.

${ }^{64}$ Amnesty International, Dark Web of Collusion, p. 48.

${ }^{65}$ United Nations Human Rights Office of the High Commissioner, 'Italy: UN Experts Condemn Criminalisation of Migrant Rescues and Threats to Independence of Judiciary' (18 July 2019), available at: \{https://www.ohchr.org/en/ NewsEvents/Pages/DisplayNews.aspx?NewsID=24833\&LangID=E\}.

${ }^{66}$ Amnesty International, Dark Web of Collusion, p. 49.

${ }^{67}$ Amnesty International and Human Rights Watch, Written Submissions on Behalf of the Interveners, S. S. and Others $v$ Italy, European Court of Human Rights, Application No. 21660/18, para. 8, available at: \{https://www.hrw.org/sites/default/ files/supporting_resources/hrw_amnesty_international_submissions_echr.pdf\}.

${ }^{68}$ Clark, The Vulnerable in International Society, p. 11.

${ }^{69}$ Goodin, Protecting the Vulnerable, p. 191.
} 
and doing so even in the face of documented cases of torture. ${ }^{70}$ The physical and psychological distance of Italy and the EU with the torture in Libya enabled them to treat migrants in a cruel way while showing indifference to their suffering. As the UN Special Rapporteur has stated in regards to pushbacks, 'In displaying complete indifference as to the grave risks which some of the affected migrants may be exposed to, "pushbacks" ... blatantly negate their human dignity in a manner which, in the view of the Special Rapporteur, is inherently degrading. ${ }^{, 71}$ European officials may not be in Libya directly torturing migrants and refugees, but they are playing a key role in the infliction of pain and suffering, even if from a distance.

As discussed in the next section below, European pushback and pullback policies formed part of the process that led to migrants and refugees being tortured in Libya. Not only did these polices contribute to the infliction of pain and suffering, but by using the law to evade responsibility for human rights abuses of returned migrants, it placed migrants and refugees out of the bounds of moral concern.

\section{Pushbacks, pullbacks, and European cooperation with Libya Pushbacks to Libya}

In 2007, 2008, and 2009, Italy and Libya signed cooperative arrangements that involved Italian police and coastguard vessels intercepting migrant boats and towing them back to Libya to prevent them from reaching Italian shores. These agreements involved developing cooperation in sea operations and intelligence sharing, training Libyan officials as well as providing them with financial and material support. ${ }^{72}$ Italy began using boat pushbacks in $2009,{ }^{73}$ and in that year, an estimated eight hundred people were pushed back by Italian authorities. ${ }^{74}$

When asked about interception of migrant vessels at sea, the then Italian Prime Minister, Silvio Berlusconi, stated that "Our idea is to take in only those citizens who are in a position to request political asylum and who we have to take in as stipulated by international agreements and treaties," referring to "those who put their feet down on our soil, in the sense also of entering into our territorial waters." ${ }^{\prime 75}$ Legal arguments used to justify this position were put forward in the 2012 ECtHR case, Hirsi Jamaa and Others v. Italy. This case concerned the pushback by Italian authorities of three migrant vessels, carrying an estimated two hundred people, to Libya in 2009. The applicants in this case argued that Italy breached their rights under Article 3, Article 4 of Protocol No. 4, and Article 13 of the European Convention on Human Rights, which, respectively, prohibits torture and ill-treatment, collective expulsions, and provides the right to a remedy. ${ }^{76}$ Italy argued that because the pushbacks occurred outside of Italian territory and on the high seas in the context of a 'rescue' operation, it did not exercise jurisdiction over the migrants. This was because it did not have "absolute and exclusive control" over' them. ${ }^{77}$ By evading jurisdiction, Italy argued that it could not be held responsible for breaches of the European Convention on Human Rights. ${ }^{78}$

\footnotetext{
${ }^{70}$ See Amnesty International, Dark Web of Collusion; Human Rights Watch, No Escape from Hell.

${ }^{71}$ United Nations Human Rights Council, Report of the Special Rapporteur, p. 15.

${ }^{72}$ Mariagiulia Giuffré, 'State responsibility beyond borders: What legal basis for Italy's push-backs to Libya?', International Journal of Refugee Law, 24:4 (2013), pp. 692-734.

${ }^{73}$ Human Rights Watch, Pushed Back, p. 4.

${ }^{74}$ Annick Pijnenburg, 'From Italian pushbacks to Libyan pullbacks: Is Hirsi 2.0 in the making in Strasbourg?', European Journal of Migration and Law, 20:4 (2018), pp. 396-426 (p. 399).

${ }^{75}$ Human Rights Watch, 'Italy: Berlusconi Misstates Refugee Obligations (12 May 2009), available at: \{https://www.hrw. org/news/2009/05/12/italy-berlusconi-misstates-refugee-obligations\}.

${ }^{76}$ Hirsi Jamaa and Others v. Italy, p. 1. For the European Convention on Human Rights, see Council of Europe, Convention for the Protection of Human Rights and Fundamental Freedoms (1950), available at: \{https://www.echr.coe.int/ Documents/Convention_ENG.pdf\}.

${ }^{77}$ Hirsi Jamaa and Others v. Italy, pp. 23-4.

${ }^{78}$ Ibid., p. 25.
} 
Second, Italy sought to evade its positive obligations under the non-refoulement principle. The non-refoulement principle prohibits the return of individuals to a country where they are at risk of persecution, such as torture. ${ }^{79}$ Just as torture is prohibited absolutely, it is prohibited absolutely to send someone to a country when there is a 'substantial risk' they will face torture. This means non-refoulement cannot be balanced with other interests, such as migration deterrence. ${ }^{80}$ However, Italy argued that because it intercepted the migrant boats in a 'rescue' operation, it was not necessary to check if people needed refugee protection. Moreover, Italy argued that it was appropriate to return the migrants and refugees to Libya as Libya was deemed a 'safe host country'. As Libya had ratified human rights treaties, such as the UN Convention against Torture (UNCAT), and committed to upholding the UN Declaration on Human Rights under the 2008 Treaty with Italy, ${ }^{81}$ Italy argued that it 'had no reason to believe that Libya would evade its commitments ${ }^{82}$ and violate the rights of returnees. Moreover, because the UNHCR operated in Libya, Italy stated that Libya was safe because asylum applications could be processed there. $^{83}$

Italy's interpretation of its international legal obligations on the high seas significantly increased the vulnerability of migrants and refugees to torture and ill-treatment. This was because it chipped away at a number of important positive obligations that come under the nonrefoulement principle. When individuals were intercepted at sea, they were not given the right to apply for asylum and Italian authorities did not conduct individual risk assessments to determine whether people would be harmed on their return to Libya. ${ }^{84}$ Individuals pushed back to Libya were denied effective remedy by being unable to challenge their return to Libya in court. ${ }^{85}$ And in being returned to Libya, refugees and migrants also risked being deported to third countries where they faced the further risk of torture. This practice, known as chain refoulement, has been of significant concern, especially for people from Somalia and Eritrea, who have been returned to these countries despite the UNHCR granting some individuals from these countries refugee status. ${ }^{86}$ Even though the UNHCR operate there, the UNHCR told the European Committee for the Prevention of Torture (CPT) that given its lack of resources in Libya, it 'does not have the power or the means to fully protect these persons', ${ }^{87}$ including from torture.

As a result, pushbacks have returned people to Libya, where they have been detained in inhumane detention centres, tortured, and ill-treated. In Al-Zawiya detention centre, where people pushed back by Italy were often sent, migrants faced inhumane conditions. Al-Zawiya was overcrowded. Human Rights Watch reported that an estimated 150 men were held in $8 \times 8$ metre rooms. ${ }^{88}$ Beatings were also constant. According to one detainee interviewed by Human Rights Watch, 'People were beaten there every day. They were knocked hard with wooden clubs. If you said you were a Christian, they would beat you and throw you in the desert. ${ }^{89}$ Other detention centres where people from interdicted boats were taken also had inhumane conditions, and individuals were beaten by officials in these centres as well. ${ }^{90}$

\footnotetext{
${ }^{79}$ See Art. 3 of the 1984 UNCAT. For a legal analysis on the non-refoulement norm in regards to the prohibition against torture, see Rodley with Pollard, The Treatment, pp. 166-79.

${ }^{80}$ See, for example, Case of Chahal v. The United Kingdom, European Court of Human Rights, 15 November 1996 (Application No. 22414/93), Strasbourg.

${ }^{81}$ Hirsi Jamaa and Others v. Italy, p. 30.

${ }^{82}$ Ibid.

${ }^{83}$ Ibid.

${ }^{84}$ Ibid., pp. $29-30$.

${ }^{85}$ Violeta Moreno-Lax, 'Hirsi Jamaa and Others v. Italy or the Strasbourg Court versus extraterritorial migration control?', Human Rights Law Review, 12:3 (2012), pp. 574-98 (pp. 589-92); Hirsi Jamaa and Others v. Italy, pp. 50-4.

${ }^{86}$ Hirsi Jamaa and Others v. Italy, p. 38.

${ }^{87}$ Council of Europe, Report to the Italian Government, p. 20.

${ }^{88}$ Human Rights Watch, Pushed Back, p. 82.

${ }^{89}$ Ibid.

${ }^{90}$ Ibid., p. 87.
} 
The risk that pushed-back migrants would be tortured and ill-treated on their return to Libya had occurred before the Italian-Libyan cooperative agreements. In July 2005, Malta pushed back a migrant vessel to Libya. On arrival, the migrants were kicked and beaten by Libyan officials with sticks, before being sent to Misrata prison, where they were beaten further. Women also faced sexual violence from guards. ${ }^{91}$ Furthermore, human rights groups have documented widespread discrimination against migrants and refugees in Libya. ${ }^{92}$ Migrants and refugees have been subjected to beatings, whippings, and electric torture, and children have endured forced labour. ${ }^{93}$

As this information about the human rights situation in Libya was available before ${ }^{94}$ the time that Italy was engaging in pushbacks, it is highly likely that it knew of the conditions in Libya. As the ECtHR stated,

The Court notes again that that situation [torture and ill-treatment in Libya] was well known and easy to verify on the basis of multiple sources. It therefore considers that when the applicants were removed, the Italian authorities knew or should have known that, as irregular migrants, they would be exposed in Libya to treatment in breach of the Convention and that they would not be given any kind of protection in that country. ${ }^{95}$

And yet, despite the documentation of human rights abuses, Italy returned migrants to Libya anyway to achieve migration deterrence goals. By denying legal responsibility, it created indifference to the pain and suffering returned migrants experienced in Libya. It placed migrants beyond moral concern. Italy was only engaging in a 'rescue' operation, and therefore, did not exercise jurisdiction over them. It was not Italy's responsibility to check whether migrants would be harmed if returned to Libya.

The European Committee on the Prevention of Torture, ${ }^{96}$ Human Rights Watch, ${ }^{97}$ and the $\mathrm{UNHCR}^{98}$ disagreed with Italy's interpretation of its international obligations, arguing that the non-refoulement principle does apply during its pushback operations. When the ECtHR handed down its ruling in Hirsi in 2012, it agreed with many of the criticisms of Italy's pushbacks made by human rights authorities. The ECtHR ruled that when Italy intercepted the migrant vessels, it had exercised extraterritorial jurisdiction as it had 'continuous and exclusive de jure and de facto control' over the migrants. ${ }^{99}$ The Court also ruled that Italy violated its non-refoulement obligations. This was because Libya was not a safe country to return people to, torture was 'tolerated by the authorities, ${ }^{100}$ people were put at risk of chain refoulement, ${ }^{101}$ and there was no opportunity to claim refugee protection or exercise their right to a remedy. ${ }^{102}$ As a result, the ECtHR found

\footnotetext{
${ }^{91}$ Ibid., pp. 38-9, 83-4.

${ }^{92}$ See also Human Rights Watch, Stemming the Flow: Abuses against Migrants, Asylum Seekers and Refugees, 18:5(E) (2006).

${ }^{93}$ Human Rights Watch, Pushed Back.

${ }^{94}$ See also Human Rights Watch, Stemming the Flow.

${ }^{95}$ Hirsi Jamaa and Others v. Italy, p. 37.

${ }^{96}$ Council of Europe, Report to the Italian Government.

${ }^{97}$ Human Rights Watch, Pushed Back.

${ }^{98}$ Hirsi Jamaa and Others v. Italy, pp. 14-15.

${ }^{99}$ Ibid., p. 27. This ruling is consistent with the recognition of extraterritorial jurisdiction by other legal and human rights authorities. See The Haitian Centre for Human Rights et al. v. United States, Case 10.675, 10.675, Inter-American Commission on Human Rights (IACHR), 13 March 1997; United Nations Committee Against Torture, General Comment No. 4 (2017) on the Implementation of Article 3 of the Convention in the Context of Article 22 (9 February 2018), available at: $\{$ https://www.refworld.org/docid/5a903dc84.html\}.

${ }^{100}$ Hirsi Jamaa and Others v. Italy, p. 36.

${ }^{101}$ Ibid., pp. $38-41$.

${ }^{102}$ Ibid., p. 54.
} 
Italy to be in breach of Article 3, Article 4 of Protocol No. 4 and Article 13 of the European Convention on Human Rights. ${ }^{103}$

This ruling was important because it not only ended Italy's pushbacks, but it also broadened the reach of human rights law to provide protections to people on the move. Nevertheless, even though Italy brought its pushbacks to an end, the Hirsi ruling led to 'creative legal thinking'104 about how Europe could continue to return migrant and refugee vessels to Libya without breaching the ECtHR's ruling. The answer was 'pullbacks'.

\section{Pullbacks to Libya}

By 2016 and 2017, the EU and Italy started to develop new forms of cooperation with Libya. ${ }^{105}$ Moving away from pushbacks, Italy and the EU supported the LCG in carrying out pullback operations. Under a 2017 Memorandum of Understanding (MoU) between Italy and Libya, ${ }^{106}$ the LCG would be trained and assisted in pulling the migrant and refugee vessels back to Libya before they could reach Europe. European support has been integral in assisting the LCG in intercepting migrant vessels. Not only has Europe provided the LCG with vessels and training, ${ }^{107}$ but they have also assisted with operations. As migrant vessels leave Libya, Italian officials will often alert the LCG as to the location of vessels so that they can be intercepted. An Italian vessel in Tripoli, for example, provides communication and control functions to the LCG that has been crucial in boat interceptions. ${ }^{108}$ Migrants have recalled that when stranded in the Mediterranean, Italian boats and helicopters have often been first to arrive. However, instead of rescuing the migrants, they inform the LCG who then pull the migrant boat back to Libya. ${ }^{109}$ Once onshore, migrants and refugees are then placed in detention centres. ${ }^{110}$

The Italian government, ${ }^{111}$ as well as the EU, ${ }^{112}$ has deemed these migration deterrence policies, and cooperation with Libya, both necessary and successful. As EU Foreign Minister, Federica Mogherini stated in 2017, 'We all know that we need to work together - the international community, Europe, Libya and neighbours - to stop the smugglers, dismantle the criminal networks, save lives and stop this human tragedy.' ${ }^{113}$ Since 2017, the LCG has become a leading actor in intercepting migrant vessels heading to Europe. ${ }^{114}$ When the agreement between Italy and Libya was renewed (without amendments) in 2020, it is estimated that since the

\footnotetext{
${ }^{103}$ Hirsi Jamaa and Others v. Italy.

${ }^{104}$ Thomas Gammeltoft-Hansen, 'International refugee law and refugee policy: The case of deterrence policies', Journal of Refugee Studies, 27:4 (2014), pp. 574-95 (p. 586).

${ }^{105}$ See European Commission, 'Joint Communication'; European External Action Service, 'EUNAVFOR MED Operation Sophia Starts Training of Libyan Navy Coast Guard and Libyan Navy', press release (27 October 2016), available at: \{https:// www.operationsophia.eu/wp-content/uploads/2018/04/eeas_-_european_external_action_service_-_eunavfor_med_operation_sophia_starts_training_of_libyan_navy_coast_guard_and_libyan_navy_-_2016-10-27.pdf\}.

${ }^{106}$ Odysseus Network, 'Memorandum of Understanding on Cooperation in the Fields of Development, the Fights against Illegal Immigration, Human Trafficking and Fuel Smuggling and On Reinforcing the Security of Borders between the State of Libya and the Italian Republic', available at: \{https:/eumigrationlawblog.eu/wp-content/uploads/2017/10/MEMORANDUM_ translation_finalversion.doc.pdf\}.

${ }^{107}$ See Forensic Oceanography, Mare Clausum: Italy and the EU's Undeclared Operation to Stem Migration Across the Mediterranean (London, UK: Forensic Architecture, Goldsmiths University of London, 2018), available at: \{https://content.forensic-architecture.org/wp-content/uploads/2019/05/2018-05-07-FO-Mare-Clausum-full-EN.pdf\}.

${ }^{108}$ Forensic Oceanography, Mare Clausum, p. 49.

${ }^{109}$ Medici Per I Diritti Umani, The Torture Factory: Report on Human Rights Violations Against Migrants and Refugees in Libya (2014-2020) (2020), p. 43 available at: \{https://mediciperidirittiumani.org\}./en/29831/\}.

${ }^{110}$ Ibid., p. 15.

${ }^{111}$ Letter from Mr Luigi Di Maio.

${ }^{112}$ European Council, Council to the European Union, 'European Council Conclusions, 28 June 2018' (29 June 2018), available at: \{https://www.consilium.europa.eu/en/press/press-releases/2018/06/29/20180628-euco-conclusions-final/\}.

${ }^{113}$ European External Action Service, 'Speech by the HRVP'.

${ }^{114}$ United Nations Support Mission in Libya, Desperate and Dangerous: Report on the Human Rights Situation of Migrants and Refugees in Libya (20 December 2018), Office of the High Commissioner for Human Rights, p. 34, available at: \{https:// reliefweb.int/report/libya/desperate-and-dangerous-report-human-rights-situation-migrants-and-refugees-libya\}.
} 
beginning of the agreement in $2017,40,000$ people have been pulled back to Libya. ${ }^{115}$ In addition to pullbacks, 'the EU supported the voluntary return of more than 50,000 migrants to their countries of origin and to the evacuation of more than 5,700 refugees and asylum-seekers out of Libya." ${ }^{116}$

According to the EU, its migration policies, as well as other anti-smuggling/trafficking operations, have and will be conducted in line with international human rights law, including nonrefoulement obligations. ${ }^{117}$ In response to criticism by human rights authorities that Libya is not a safe place to send migrants and refugees, ${ }^{118}$ Italy $^{119}$ and the EU have argued that they are providing humanitarian assistance and support to improve human rights standards in Libya. EU Commissioner for Migration Dimitris Avramopoulos stated in 2019 that, 'The EU's priority has always been and continues to be to prevent people from risking their lives on dangerous journeys, as well as providing protection and support to vulnerable people along the migratory routes. ${ }^{120}$ To assist with this, the EU has provided funding for 'training, improved registration of migrants and asylum seekers, and help getting a limited number of people out of abusive detention', ${ }^{121}$ as well as provided support to humanitarian organisations. ${ }^{122}$ For example, the EU is providing funding to the UN High Commissioner for Refugees (UNHCR) and the International Organization for Migration (IOM) to assist with the voluntary return of migrants ${ }^{123}$ and to improve detention centre conditions. ${ }^{124}$

However, despite EU proclamations that it is taking measures to improve the human rights of migrants and refugees, the EU and Italy has in fact whittled them away. Supporting Libya to carry out the pullbacks at sea allows Italy to evade a key element of the Hirsi ruling: extraterritorial jurisdiction. ${ }^{125}$ By arguing that Italy can support LCG pullbacks, but not exercise jurisdiction over the operations, it not only avoids legal liability for human rights violations in Libya, but it also evades non-refoulement obligations. As with pushback operations, pullbacks do not provide people with the right to apply for asylum or provide migrants and refugees with non-refoulement protections. ${ }^{126}$ As Annick Pijnenburg has argued, 'the current practices [of pullbacks] can be seen as circumventing the Hirsi judgement, whereby Italy hopes to obtain the same result of reducing migration flows as through pushbacks but without incurring any

\footnotetext{
${ }^{115}$ Amnesty International, 'Libya: Renewal of Migration Deal Confirms Italy's Complicity in Torture of Migrants and Refugees' (30 January 2020), available at: \{https://www.amnesty.org/en/latest/news/2020/01/libya-renewal-of-migrationdeal-confirms-italys-complicity-in-torture-of-migrants-and-refugees/\}.

${ }^{116}$ European Parliament, 'Answer Given by Ms Johansson on Behalf of the European Commission', Parliamentary Questions (11 September 2020), Question reference: E-003486/2020, available at: \{https:/www.europarl.europa.eu/doceo/ document/E-9-2020-003486-ASW_EN.html\}.

${ }^{117}$ CCouncil Decision (CFSP) 2015/778 of 18 May 2015 on a European Union Military Operation in the Southern Central Mediterranean (EVNAVFOR MED)', Official Journal of the European Union (19 May 2015), L 122/31; Council of the EU, 'Malta Declaration by the Members of the European Council on the External Aspects of Migration: Addressing the Central Mediterranean Route' (3 February 2017), available at: \{https:/www.consilium.europa.eu/en/press/press-releases/2017/02/03/ malta-declaration/\}.

${ }^{118}$ See, for example, Amnesty International, Dark Web of Collusion.

${ }^{119}$ See Amnesty International and Human Rights Watch, Written Submissions, para. 16.

${ }^{120}$ European Parliament, 'Answer Given by Mr Avramopoulos on Behalf of the European Commission', Parliamentary Questions (25 June 2019), Question reference: E-001793/2019, available at: \{https://www.europarl.europa.eu/doceo/document/E-8-2019-001793-ASW_EN.pdf\}.

${ }^{121}$ Human Rights Watch, No Escape from Hell, p. 21.

${ }^{122}$ Ibid., p. 27.

${ }^{123}$ European Commission, 'Joint Communication'.

${ }^{124}$ Human Rights Watch, No Escape from Hell, pp. 27-8.

${ }^{125}$ Gammeltoft-Hansen, 'International refugee law', p. 587.

${ }^{126}$ Amnesty International, Dark Web of Collusion.
} 
responsibility. ${ }^{127}$ Italy, with EU support, is utilising international cooperation with neighbouring states to get them to carry out practices prohibited to Italy.

Similar to pushbacks, as Italy and the EU used the law to evade jurisdiction, as well as responsibility over migrants, it excluded migrants from moral concern. Italy and the EU have played an important contributing role in pullback operations but deny any responsibility in contributing to the torture that often results from these policies. Migrants and refugees have been pulled into situations where they have faced an increased risk of torture and ill-treatment from the moment of interception by Libyan authorities to when they are detained in Libya. When migrants are intercepted by the LCG, people have reported that the LCG use violent, abusive, and dangerous practices to get people to return to Libya. Reports include LCG officers boarding migrant boats and hitting them with batons, ${ }^{128}$ whipping people with hoses, ${ }^{129}$ and using 'threatening or racist language'. ${ }^{130}$ The LCG also intimidate migrant boats by 'colliding with vessels in distress ${ }^{\text {'131 }}$ and approaching migrant boats at high speed, causing waves and the migrant boat to destabilise. ${ }^{132}$

Once migrants are brought back to Libya, they are detained in inhumane conditions from anywhere from a few weeks to years. ${ }^{133}$ According to the UN, 'Those detained have no possibility to challenge the legality of their detention, and no access to legal aid. ${ }^{, 34}$ Detention centres, which are run by Libyan authorities, and unofficial centres, operated by militias or people smugglers, detain migrants until they are deported or able to pay for their release. ${ }^{135}$ However, the detention facilities are unfit for detention. There is overcrowding, lack of personal space to the point where 'people are unable to stretch out at night', ${ }^{136}$ as well as a lack of food and water. ${ }^{137}$ As a result, detainees have developed 'respiratory tract infections, acute watery diarrhea, skin diseases, and urinary tract infections' because of the conditions. ${ }^{138}$

Alongside inhumane conditions, migrants are subjected to routine violence in detention. The abuse is carried out by Libyan authorities, militias, or people smugglers. ${ }^{139}$ Torture and beatings are systemic. Médicins Sans Frontières (MSF) interviewed asylum seekers and migrants who had been rescued by MSF's search and rescue vessel, Dignity, and found that up to ' $92 \%$ of people reported having been direct victims of some form of violence in Libya, with nearly $100 \%$ reporting having witnessed intentional violence perpetrated against people. ${ }^{\prime 140}$ Torture and ill-treatment includes beatings with 'sticks, rocks, and metal bars', with some reporting loss of eyesight and hearing as a result. ${ }^{141}$ Migrants are forced to sit outside and stare at the sun, ${ }^{142}$

\footnotetext{
${ }^{127}$ Pijnenburg, 'From Italian pushbacks', p. 407.

${ }^{128}$ Amnesty International, A Perfect Storm, p. 24.

${ }^{129}$ United Nations Support Mission in Libya, Desperate and Dangerous, p. 37.

${ }^{130}$ Ibid., p. 35.

${ }^{131}$ Ibid.

${ }^{132}$ Amnesty International, A Perfect Storm, p. 25.

${ }^{133}$ Medici Per I Diritti Umani, Torture Factory.

${ }^{134}$ United Nations Human Rights Office of the High Commissioner, 'UN Human Rights Chief: Suffering of Migrants in Libya Outrage to Conscience of Humanity' (14 November 2017), available at: \{https:/www.ohchr.org/EN/NewsEvents/Pages/ DisplayNews.aspx?NewsID=22393\&LangID=E\}.

${ }^{135}$ Medici Per I Diritti Umani, Torture Factory.

${ }^{136}$ Médicins Sans Frontières, 'Libya: MSF Teams Providing Medical Care to Detained Refugees and Migrants' (13 December 2016), available at: \{https://www.doctorswithoutborders.org/what-we-do/news-stories/news/libya-msf-teams-providing-medical-care-detained-refugees-and-migrants\}.

${ }^{137}$ Ibid.

${ }^{138}$ Ibid.

${ }^{139}$ See Amnesty International, Dark Web of Collusion; Human Rights Watch, No Escape from Hell.

${ }^{140}$ Médicins Sans Frontières, Turning a Blind Eye: How Europe Ignores the Consequences of Outsourced Migration Management (November 2015), p. 12, available at: \{https://arhp.msf.es/sites/default/files/Turning-a-blind-eye-ENG-091115.pdf\}.

${ }^{141}$ United Nations Support Mission in Libya, 'Detained and Dehumanised': Report on Human Rights Abuses against Migrants in Libya, Office of the United Nations High Commissioner for Human Rights (December 2016), p. 17, available at: \{https://www.ohchr.org/Documents/Countries/LY/DetainedAndDehumanised_en.pdf\}.

${ }^{142}$ Human Rights Watch, No Escape from Hell, p. 35.
} 
and have endured 'burning with cigarettes, electric shocks, and whippings while being hung from a tree'. ${ }^{143}$ Detainees reported being subjected to the torture technique 'falaka', which is the beating on the soles of the feet, ${ }^{144}$ and being forced to have sex at gunpoint with other detainees. ${ }^{145}$ Children are not spared from violence, ${ }^{146}$ and women are subjected to rape and forced into sex work. ${ }^{147}$ People smugglers often give women contraception because of the high risk of them getting raped on their journey to Europe. ${ }^{148}$ In one harrowing case, a woman from the Ivory Coast recalls her experience in Sabha detention camp, run by people smugglers:

Libya was hell. I am cursed, I'm actually cursed. In Sabha they took me and brought me to prison, they wanted money from me. I was in prison for seven months: from September 2016 til April 2017. They did everything to me! Every day they took us and they brought us to some men to satisfy their pleasures. They raped me from the front and the back, they were so violent that afterwards I had difficulties even sitting down. They filmed me while they raped me. They urinated on me! One day they forced me to have a sexual intercourse with a dog and they filmed me. I'm cursed. ${ }^{149}$

A particularly disturbing practice that has emerged in Libya in recent years has been the rise of slavery auctions. ${ }^{150}$ There is believed to be an estimated nine locations in Libya where slave auctions happen, ${ }^{151}$ with individuals being sold from anywhere between $\$ 100-\$ 400$ each. ${ }^{152}$ One of the reasons for the emergence of the slavery rings is that 'a recent clampdown by the Libyan coastguard means fewer boats are making it out to sea, leaving the smugglers with a backlog of would-be passengers on their hands. ${ }^{, 53}$ According to CNN, which has reported on slavery in Libya, the result was that 'the smugglers become masters, the migrants and refugees become slaves. ${ }^{154}$ In some cases, migrants are sold more than once if their debt is not covered, ${ }^{155}$ and people often suffer torture and ill-treatment in slavery. ${ }^{156}$ The CNN journalists stated after witnessing an auction, they 'met two of the men who had been sold. They were so traumatized by what they'd been through that they could not speak, and so scared that they were suspicious of everyone they met.'157

Torture and ill-treatment does not stop at the migrants. Migrants' family members are also subjected to psychological harm by Libyan authorities. Libyan authorities have kidnapped and

\footnotetext{
${ }^{143}$ Ibid.

${ }^{144}$ Medici Per I Diritti Umani, Torture Factory, pp. 11, 21, 27, 37.

${ }^{145}$ Ibid., p. 30.

${ }^{146}$ UNICEF, A Deadly Journey for Children: The Central Mediterranean Migration Route (February 2017), available at: \{https://www.unicef.org/reports/deadly-journey-children\}.

${ }^{147}$ United Nations Support Mission in Libya, 'Detained and Dehumanised', p. 21.

${ }^{148}$ Nima Elbagir, Lillian Leposo, and Hassan John, “Don't struggle if you're raped”: People smuggler gives chilling warning to undercover CNN reporter', CNN (28 February 2018), available at: \{https://edition.cnn.com/2018/02/27/africa/nigeriamigrant-smugglers-intl/index.html\}

${ }^{149}$ Medici Per I Diritti Umani, Torture Factory, p. 20.

${ }^{150}$ See Mark Akkerman, Expanding the Fortress: The Policies, the Profiteers and the People Shaped by EU's Border Externalisation Programme (Transnational Institute and Stop Wapenhandel, 2018), p. 8.

${ }^{151}$ Richard Roth, 'UN chief: Libya slave auctions may be crimes against humanity', CNN (20 November 2017), available at: \{https://edition.cnn.com/2017/11/20/africa/un-secretary-general-libya-slave-auctions/index.html\}.

${ }^{152}$ See Medici Per I Diritti Umani, Torture Factory, p. 29; see Nima Elbagir, Raja Razek, Alex Platt, and Bryony Jones, 'People for sale', CNN (14 November 2017), available at: $\{$ https://edition.cnn.com/2017/11/14/africa/libya-migrant-auctions/index.html\}.

${ }^{153}$ See Elbagir, Razek, Platt, and Jones, 'People for sale'.

${ }^{154}$ Ibid.

${ }^{155}$ Medici Per I Diritti Umani, Torture Factory, p. 39.

${ }^{156}$ Ibid., p. 29.

${ }^{157}$ Elbagir, Razek, Platt, and Jones, 'People for sale'.
} 
tortured migrants to extort their family members for money. ${ }^{158}$ Sometimes, the torture happens while the family member is on the phone. According to one migrant in detention, 'They asked me to call my family to ask for money, but I had lost all contacts so I never called. But I saw one boy in the prison - they gave him a phone to call the family, and they beat him with a metal stick while [he was] on the phone, on arms and everywhere. ${ }^{159}$ In another case, people smugglers tortured 75 migrants, recorded it on Facebook, and then sent the videos to family members of the migrants. ${ }^{160}$ When migrants cannot pay the ransom, they are often made to carry out forced labour, sold into slavery rings, ${ }^{161}$ or are tortured and killed. ${ }^{162}$

None of this treatment is inevitable. And neither is the vulnerability of migrants to torture and ill-treatment. Instead of creating safe migration pathways, Italy and the EU have made them more dangerous. Italy and the EU have evaded both jurisdictional issues as well as obligations under the non-refoulement principle by getting Libya to engage in conduct that the ECtHR ruled was prohibited to European states. This meant that migrants and refugees received no protection under the non-refoulement principle and were denied the ability to apply for the right to asylum. Human rights standards have also been neglected. Human rights abuses in Libya have been recognised by Italian and EU government officials, ${ }^{163}$ however, they have failed to include human rights safeguards within arrangements with Libya. ${ }^{164}$ Not only did the $2017 \mathrm{MoU}$ between Italy and Libya contain no human rights conditions for providing support to Libya, ${ }^{165}$ but as the UN Human Rights Commissioner has noted, 'The increasing interventions of the EU and its member states have done nothing so far to reduce the level of abuses suffered by migrants ... Our monitoring, in fact, shows a fast deterioration in their situations in Libya. ${ }^{166}$ European actors are showing moral indifference to the human suffering that is resulting from their actions. The interests of refugees and migrants have been neglected as Italy and the EU have privileged efforts to stop boat arrivals in Europe over considerations for the well-being of people on the move.

\section{Challenging cruelty and indifference}

Pushback and pullback policies show how Italy and the EU are part of the process that has led to migrants and refugees being tortured on their return to Libya. They not only funded and provided material support to Libya, but also took part in the pushbacks themselves, or, assisted Libya in pulling back boats. The intimate involvement of Italy and the EU means that they share responsibility for the torture and ill-treatment of returned migrants. Despite claims by EU officials that they are abiding by international law and upholding their human rights obligations, they have taken significant measures to exacerbate the vulnerability of migrants and refugees to torture and ill-treatment by stripping important human rights protections that, otherwise, would have prevented them from being returned to Libya.

Italy and the EU are not ignoring or dismissing international law. They are using it to return people back to Libya. International law has a productive power in that it both constrains and

\footnotetext{
${ }^{158}$ Médicins Sans Frontières, Trapped in Transit: Refugees, Migrants and Asylum Seekers Locked Up In Libya (22 July 2016), available at: $\{$ https://msf.exposure.co/trapped-in-transit\}.

${ }^{159}$ Amnesty International, Dark Web of Collusion, p. 32.

${ }^{160}$ William Lacy Swing, 'The abuse of migrants in Libya is a blot on the world's conscience', CNN (14 November 2017), available at: $\{$ https://edition.cnn.com/2017/11/14/opinions/libya-migrants-protected-opinion-lacy-swing/index.html\}.

${ }^{161}$ Medici Per I Diritti Umani, Torture Factory.

${ }^{162}$ United Nations Support Mission in Libya, 'Detained and Dehumanised', p. 17.

${ }^{163}$ See Amnesty International and Human Rights Watch, Written Submissions, para. 16.

${ }^{164}$ United Nations Committee against Torture, Concluding Observations on the Combined Fifth and Sixth Periodic Reports of Italy (18 December 2017), Doc. No: CAT/C/ITA/CO/5-6, p. 5.

${ }^{165}$ Amnesty International and Human Rights Watch, Written Submissions, para. 17.

${ }^{166}$ United Nations Human Rights Office of the High Commissioner, 'UN Human Rights Chief: Suffering of Migrants in Libya Outrageto Conscience of Humanity' (14 November 2017), available at: \{https://www.ohchr.org/EN/NewsEvents/ Pages/DisplayNews.aspx?NewsID=22393\&LangID=E .
} 
enables state actions, ${ }^{167}$ including by legitimising violence and harm. ${ }^{168}$ The strategic use of international law is integral in understanding how Italy and the EU are engaging in cruelty. Bauman's recognition that cruelty can occur at a distance, and can be carried out through laws and bureaucratic procedures, helps establish the connection between pushback and pullback policies and the infliction of pain and suffering on migrants and refugees in Libya. Such legal manoeuvring also helps understand how Italy and the EU continue to send migrants to Libya in the face of serious human rights violations. The law is used to help Italy and the EU evade responsibility for the harm carried out in Libya. ${ }^{169}$

But the use of international law to evade responsibility also helped place migrants and refugees beyond moral concern. As Bauman notes, increasing both physical and psychological distance makes the infliction of cruelty not only easier, but also generates moral indifference to the suffering it causes. Bauman argues, 'It is difficult to harm a person we touch. It is somewhat easier to afflict pain upon a person we only see at a distance. It is still easier in the case of a person we only hear. It is quite easy to be cruel towards a person we neither see nor hear. ${ }^{170}$ This indifference can be seen in the refusal of European countries to stop returning migrants to Libya, even in the face of human rights abuses. When the Council of Europe Human Rights Commissioner Danja Mijatovic wrote to the Italian Minister for Foreign Affairs and International Cooperation Luigi Di Maio in 2020, asking him to suspend Italy's cooperation with Libya because of human rights concerns, ${ }^{171}$ the Foreign Minister refused. Foreign Minister Di Maio replied stating that cooperation with Libya has been effective and would continue. Acknowledging human rights concerns, he stated, 'We are fully aware that there is room for improvement in the cooperation established in 2017 with Libya, but figures as such tell us that we have to keep working along this direction, rather than disengaging from the country. ${ }^{172}$ Improvements would occur in the future, the Foreign Minister stated, that would incorporate human rights standards. ${ }^{173}$

Other European leaders and diplomats have made similar responses to the poor human rights situation in Libya, where the suffering of migrants was either invisible, or considered less important than achieving migration deterrence. Germany's Interior Minister stated in 2017, 'I'm happy that the number of people sent across the Mediterranean by the smugglers to Italy has really fallen in the last two months ... These developments need to be carried on. ${ }^{174}$ And in regards to the EU's ongoing support for Italy's migration deterrence policies, an EU diplomat told journalists, 'Some of the methods may seem controversial. But there is also preventing loss of life at the sea and political stability in Italy to consider. We shouldn't be too judgmental. ${ }^{175}$ The fact that torture was known about not only before the Hirsi ruling, but also after, and Italy and EU officials still decided to send people there anyway, shows how migrants and refugees have been excluded from moral concern. They have become the unfortunate, but apparently necessary, collateral damage of efforts to stop boat arrivals in Europe.

However, what this article has also shown is that international law can also be used to challenge these policies and extend moral boundaries. The defeat of Italy's pushback operations in

\footnotetext{
${ }^{167}$ Hurd, International Law.

${ }^{168}$ See Kennedy, A World of Struggle; Kennedy, Of War and Law; Craig A. Jones, 'Frames of law: Targeting advice and operational law in the Israeli military', Environmental Planning D: Society and Space, 33:4 (2015), pp. 676-96; Craig A. Jones, 'Lawfare and the juridification of law modern war', Progress in Human Geography, 40:2 (2016), pp. 221-39.

${ }^{169}$ Veitch, Law and Irresponsibility.

${ }^{170}$ Bauman, Modernity and the Holocaust, p. 155.

${ }^{171}$ Letter to Mr Luigi Di Maio, Minister of Foreign Affairs and International Cooperation of Italy, from Dunja Mijatovic, Council of Europe Commissioner for Human Rights (13 February 2020), ref: CommHR/DM/sf006-2020, available at: \{https:// rm.coe.int/letter-to-mr-luigi-di-maio-minister-of-foreign-affairs-and-internation/16809c8262\}

${ }^{172}$ Letter from Mr Luigi Di Maio.

${ }^{173}$ Ibid.

${ }^{174}$ Gabriela Baczynska, 'EU sticks to Libya strategy on migrants, despite human rights concerns', Reuters (15 September 2017), available at: \{https://www.reuters.com/article/us-europe-migrants-libya-italy-idUSKCN1BP2CQ\}.

${ }^{175}$ Ibid.
} 
the ECtHR shows how international law can constrain states and establish responsibility for harm outside of sovereign territory. ${ }^{176}$ At the time of writing, Italy has again been taken to the ECtHR in the case of S. S. and others v. Italy in regards to its pullback operations. A number of arguments have been made against pullbacks. First, Amnesty International and Human Rights Watch argue in their intervening submission in the case that even though Libya is the country pulling back boats, Italy is still exercising jurisdiction. The interveners argue, 'in view of the extent and pervasiveness of Italy's role in Libya's migration and SAR [search and rescue] system, Libya has acted under its decisive influence since at least 2017, to an extent that Italy should be found to have exercised jurisdiction, at least concurrently with Libya, in migration-related operations conducted by Libyan forces. ${ }^{177}$ This would extend the Hirsi judgement by showing that jurisdiction is not always linked to territory, but can also be present when states exercise control over others outside of their territory.

Second, human rights actors have argued that pullbacks are in violation of the nonrefoulement principle. Forensic Oceanography has argued that pullbacks represent 'refoulement by proxy' as the 'Libyan agencies [are] acting under the control and direction of Italian and EU authorities. ${ }^{, 178}$ Likewise, the UN Special Rapporteur on Torture has stated that pullbacks could breach the non-refoulement principle, arguing,

when 'pullbacks' forcibly retain migrants in situations where they are exposed to a real risk of torture and ill-treatment, any participation, encouragement, or assistance provided by destination States for such operations would be irreconcilable with a good faith interpretation and performance of the prohibition of torture and ill-treatment, including the principle of non-refoulement. ${ }^{179}$

And third, interveners in the court case have argued that Italy could be complicit in the human rights violations occurring in Libya. ${ }^{180}$ Because Italy is providing so much material, logistical, and financial support to enable the pullbacks to occur, interveners have argued that Italy could be legally responsible for aiding wrongful conduct under the principle of State Responsibility. ${ }^{181}$ Aiding a state in wrongful conduct is not just about assisting another state, but it is also about failing to bring the wrongful conduct to an end. ${ }^{182}$ In the case of Italy, it has not only provided assistance to Libya, but also failed to take effective measures to stop the torture and ill-treatment from occurring.

Interpreting international law in a manner that recognises Italian jurisdiction over Libyan pullback operations, its violation of the non-refoulment principle, and Italy's complicity in wrongful conduct, will strengthen the link between Italy's conduct and the torture and ill-treatment experienced in Libya. Although challenging Europe's migration policies in the ECtHR will not be easy, ${ }^{183}$ this ongoing struggle over international law demonstrates that change is possible. Just like the ECtHR's decision in Hirsi, recognising Italian jurisdiction would help establish the responsibility that Italy and the EU have in shaping conditions on the ground in Libya. In

\footnotetext{
${ }^{176}$ See Thomas Gammeltoft-Hansen and James C. Hathaway, 'Non-Refoulement in a world of cooperative deterrence', Columbia Journal of Transnational Law, 53:2 (2015), pp. 235-84.

${ }^{177}$ Amnesty International and Human Rights Watch, Written Submissions, para. 7.

${ }^{178}$ Forensic Oceanography, Mare Clausum, p. 8.

${ }^{179}$ United Nations Human Rights Council, Report of the Special Rapporteur, p. 16.

${ }^{180}$ See Aire Centre, The Dutch Refugee Council, The European Council on Refugees and Exiles, and the International Commission of Jurists, Written Submission, S. S. and Others v. Italy, European Court of Human Rights, Application No. 21660/18, pp. 9-10, available at: \{https://www.icj.org/wp-content/uploads/2019/11/ECtHR-SS_v_Italy_final-JointTPIICJECREAIREDCR-English-2019.pdf\}.

${ }^{181}$ Aire Centre et al. Written Submission, pp. 9-10.

${ }^{182}$ Ibid., p. 9.

${ }^{183}$ See Pijnenburg, 'From Italian pushbacks'.
} 
doing so, it could help to challenge practices of cruelty by making it harder for European actors to place the interests of migration deterrence above the protection and well-being of migrants and refugees.

\section{Conclusion}

Migrants and refugees face the risk of torture and ill-treatment throughout their migration journey from when they leave their country of origin to when they arrive to a new country. However, these risks of harm are not natural or inevitable. Vulnerability to torture has been constructed and distributed by specifically designed migration deterrence policies. As Italy and the EU have pushed and pulled people back to Libya to achieve migration deterrence goals, these policies have made people situationally vulnerable to torture and ill-treatment. Pushbacks and pullbacks trap people in inhumane detention centres in Libya, strip them of their right to apply for asylum and right to remedy, and violate the important principle of non-refoulement.

This article has argued that these European pushbacks and pullbacks are an exercise of cruelty. Defining European pushbacks and pullbacks as a form of cruelty provides a means to critique migration policy more deeply. The concept of cruelty not only pays attention to the infliction of pain, but it also focuses on the element of indifference to human suffering. In the case of European pushbacks and pullbacks, Italy and the EU are not physically torturing people in Libya, nor are they intentionally inflicting pain for pleasure. Rather, the cruelty of European migration policies comes from how the use of rules and laws contribute to harm and the indifference European actors are showing to the consequences of their actions. As Italy and the EU narrowly define their international legal obligations, migrants and refugees are placed out of moral concern as jurisdiction, and legal responsibility, is denied. The fact that boat pushbacks and pullbacks are returning people into the hands of torturers is considered to be the unfortunate side effect of stopping migrant vessels from arriving on European shores. The responsibility for the torture, these actors argue, is with Libyan officials and people smugglers engaging in the torture, not European officials. This makes such policies extremely dangerous, as the denial of responsibility, and the indifference to suffering this generates, has enabled Italy and the EU to continue to return people to Libya, even in the face of widespread human rights violations.

Examining how states and other actors can be responsible for cruelty inflicted upon migrants and refugees in distant countries is particularly important as more and more states are aiming to control migration and refugee movements remotely. ${ }^{184}$ Just because states take measures to prevent migrant and refugee arrivals by intercepting them outside of their territory does not mean they can evade responsibility for the pain and suffering that result from these policies. Examining how vulnerability to torture is exacerbated through manipulation of international law not only helps to develop a deeper understanding of responsibility for torture and ill-treatment along migration journeys, but it also shows how the manipulation of law can contribute to moral indifference. If more states adopt similar migration deterrence policies, there is the risk that the narrow interpretation of international law will undermine obligations to migrants and refugees worldwide, creating more 'unworthy' people that are placed beyond moral concern.

It is therefore crucial to understand not only how these policies are generating harm, but also how to reform them. Although this article has examined the role that manipulation of laws can play in avoiding responsibility for harm and generating moral indifference to human suffering, it has also shown how international law can be used as a tool to challenge these policies. Human rights authorities, as well as human rights courts, have played an important role in bringing Italian pushbacks to an end, as well as expanding the reach of human rights law. What this shows is that how international law is used is important. It can help to justify migration

${ }^{184}$ Fitzgerald, Refuge Beyond Reach. 
deterrence policies and generate indifference to human suffering, or, it can be used to challenge these policies and expand moral boundaries.

Because the vulnerability to torture and cruel treatment against migrants and refugees is not inevitable, but a side effect of deliberately chosen policies, the distribution of vulnerability cannot, therefore, be separated from the ethical issue associated with this distribution. ${ }^{185}$ Continuing to exercise indifference to the side effects of pushbacks and pullbacks degrades human dignity and contributes to the torture and ill-treatment experienced by migrants and refugees. This places an ethical obligation on states, and the international community as a whole, to change their migration policies to privilege human rights over migration deterrence goals. An integral part of creating safe migration pathways, therefore, is to ensure that international law is not only shaped in a manner that protects those most susceptible to harm, but is used to extend bonds of solidarity with those travelling between states.

Acknowledgements. I would like to thank the editors at Review of International Studies and several anonymous reviewers for their valuable and constructive feedback on earlier versions of this manuscript.

Dr Jamal Barnes is a lecturer in the School of Arts and Humanities at Edith Cowan University. His research interests include human rights, torture, migration, and international security. He is the author of the book, A Genealogy of the Torture Taboo (Routledge, 2017).

\footnotetext{
${ }^{185}$ See Goodin, Protecting the Vulnerable; Clark, The Vulnerable in International Society.
}

Cite this article: Barnes, J. 2022. Torturous journeys: Cruelty, international law, and pushbacks and pullbacks over the Mediterranean Sea. Review of International Studies 48, 441-460. https://doi.org/10.1017/S0260210522000110 